\title{
REPRESENTAÇÃO, RETRATO E DRAMA ${ }^{1}$
}

Cicero Araujo

Gostaria de explorar, neste artigo, duas metáforas artísticas para a representação política. Recorrer a imagens do mundo das artes não é propriamente uma idéia original na tradição do pensamento político, mas busco fazer algo nessa direção tendo em conta uma elaboração mais abstrata, realizada em outra ocasião, sobre modos de conceituar a autoridade soberana e a boa ordem política: o Estado, da tradição contratualista moderna, e a Constituição Mista, derivada do pensamento republicano clássico, antigo e moderno (Araujo, 2004). O objetivo é relacionar essas idealizações com problemas teóricos e práticos da representação.

Ao empregar tais metáforas, não pretendo exibir nenhum estudo rigoroso e abrangente das representações artísticas. A idéia do texto é deixar que elas simplesmente abram o caminho para certas noções intuitivas que a elaboração abstrata nem sempre permite entrever, fazendo delas uma plataforma para discutir, sobrepondo-as, concepções

1. Sou grato às observações e críticas feitas por Adrián Gurza Lavalle a uma primeira versão deste texto. Naturalmente, as lacunas e equívocos que permanecerem no artigo são de minha inteira responsabilidade. 
de soberania e representação. Assim, inicialmente, farei uma caracterização da soberania estatal, inspirado na forma clássica introduzida por Hobbes, elaborando através dela noções de representação que penso apropriadas a esse tipo de soberania. Vou me valer, nessa elaboração, da metáfora do retrato. Em seguida, examino o tipo de soberania subjacente à Constituição Mista, e desdobro noções de representação correspondentes, guiado pela metáfora do drama. Finalmente, comparo as duas idealizações e aponto os modos diferenciados com que o ardiloso problema do controle da representação se apresenta para cada uma. Apesar de estruturado para revelar certas vantagens da Constituição Mista, a intenção principal do artigo é expor as razões da diferença e suas implicações.

\section{As máscaras e a política}

Num sentido bem amplo, a representação se confunde com 230 a invenção da própria política. É verdade que há um sentido mais estrito no qual ela é atributo da política moderna. Os gregos e romanos da Antigüidade, por exemplo, desconheciam as estruturas parlamentares de representação. Mas Robert Dahl tem razão quando, ao discutir o problema da escala na chamada "democracia direta", afirma que, mesmo numa assembléia de cidadãos como as que os atenienses realizavam, sendo impossível que todos pudessem falar, os oradores tinham de exercer suas habilidades para "representar" em seus discursos o pensamento alheio: "A large meeting - say, a thousand or more people - is inherently a kind of 'representative' system because a few speakers have to represent the voices of all those who cannot speak" (Dahl, 1989: 228).

Como Pitkin destaca (ver o artigo da autora neste volume), representar significa, em diversas línguas européias desde fins do Medievo, colocar-se no lugar de algo ou alguém ou, para enfatizar sua dimensão jurídica e política, agir no lugar de $\mathrm{e}^{2}$. Porém, antes de colocar o acento dessa 
atividade na substituição, como a crítica da representação moderna costuma fazer, é preciso chamar atenção para a idéia de deslocamento que ela sugere. Ao representar, procuramos nos distanciar de nós mesmos e, talvez, também daqueles que nos são muito próximos, para, através de gestos, discursos etc. abarcar ou incorporar o estranho (seus pensamentos? desejos? interesses?). Mas essa bem pode ter sido a atividade inaugural da política: estudos de historiadores-antropólogos, como o clássico trabalho de Fustel de Coulanges, sugerem que o surgimento da polis grega possibilitou um modo de superar os aspectos tribais ou de clã (fundados na genos da era arcaica) de uma etapa anterior de sua civilização, e assim fundar uma associação mais inclusiva.

Será coincidência que, mais ou menos nessa mesma época, o teatro grego tenha sido inventado? Para um teórico que aparentemente detestava tanto a política antiga, em particular a democracia ateniense, essa conexão não deixou de escapar a Thomas Hobbes. Ao falar da "pessoa" do soberano como um "representante", no tão citado capítulo XVI do Leviatã, eis as suas observações preliminares:
"A palavra 'pessoa' é de origem latina. Em lugar dela os gregos tinham prósopon, que significa rosto, tal como em latim persona significa o disfarce ou a aparencia exterior de um homem, imitada no palco. E por vezes mais particularmente aquela parte que disfarça o rosto, como máscara ou viseira. E do palco a palavra foi transferida para qualquer representante da palavra ou da ação, tanto nos tribunais

\footnotetext{
2. A noção específica de representar como colocar-se ou agir no lugar de alguém (outro ser humano) parece ter sido um pouco posterior na lingua inglesa. Em seu livro sobre o assunto, Pitkin lembra diferenças relevantes entre representar como estar no lugar de (standing for), que é mais apropriada para a representação "descritiva" e "simbólica", e agir no lugar ou em nome de (acting for). O último parece mais adequado ao conceito político de autorização (Pitkin, 1967: 38 e ss.), sobre o qual falarei mais a seguir.
} 
como nos teatros. De modo que uma pessoa é o mesmo que um ator, tanto no palco como na conversação corrente. E personificar é representar, seja a si mesmo ou a outro; e daquele que representa outro diz-se que é portador de sua pessoa, ou que age em seu nome [...] Recebe designações diversas, conforme as ocasiões: representante, mandatário, lugar-tenente, vigário, advogado, deputado, procurador, ator, $\mathrm{e}$ outras semelhantes" (Hobbes, 1983, cap. XVI: 96).

Daqui a pouco devo enfocar a dimensão plástica da idéia de máscara que aparece nessa passagem. Antes, cabe insistir nesse vínculo entre "pessoa" e "ator" marcado por Hobbes, que diz ocorrer tanto no "palco" quanto na "conversação corrente". De fato, estamos colocados diante de uma situação humana de interlocução, na qual se faz imprescindível uma atitude de abertura intelectual e mesmo emocional entre as partes, para que a própria interlo232 cução possa ocorrer. A conversa, por exemplo, dificilmente poderia acontecer se de cada parte não houvesse a disposição para trazer para dentro de si os pensamentos alheios - e também (como os teóricos morais setecentistas da "simpatia” vão insistir) os sentimentos - para então compreender o que estaria em jogo. Anatol Rosenfeld diz que foi exatamente essa descoberta que possibilitou o teatro grego, em particular, a invenção do ator. O uso da máscara por um coro, por exemplo, já feito em festivais dionísicos - em que se encenavam os ditirambos e os burlescos "autos de sátiros" - e depois aplicado nas (nada burlescas) tragédias, marcava claramente a idéia de autotransformação necessária à atuação teatral:

"A aparente contradição de que a tragédia teria resultado tanto dos autos satirescos como dos ditirambos encontra solução à base da hipótese de que tais ditirambos eram cantados e dançados, num jogo ritual em homenagem a Dioniso, por um coro, cujos membros (inicialmente 
cinqüenta coreutas) se apresentavam mascarados de sátiros. Isso corresponde ao uso freqüente da máscara ritual, que transmite aos portadores as forças e qualidades dos demônios ou deuses representados; corresponde também ao fato de Dioniso ter sido o deus da máscara e, em extensão, da metamorfose, fenômeno essencial da arte cênica: tanto os atores como os espectadores se 'transformam' nos seres representados, comungando, mercê da identificação, com seus destinos" (Rosenfeld, 1993: 48).

Em sua analogia entre o ator e o "soberano representante", Hobbes propõe a figura do "autor", que obviamente complementa a do ator. Em ambos os pólos da analogia, porém, o autor é uma figura que não deve aparecer em cena: ele a cria, possibilita intelectualmente, porém não se apresenta nela, permanece como que oculto. Na analogia hobbesiana, o autor é o "ser representado", mas que se metamorfoseia inteiramente no "ser representante", que então passa a fazer tudo no "lugar de" ou "em nome de" outro. É curioso que Hobbes não fale nada, naquela passagem citada, sobre as personagens que o autor teatral cria, a fim de representar na cena outras coisas - outras pessoas, humanas ou divinas, e mesmo objetos - e não a si mesmo, como autor. A analogia parece perder sua força nesse ponto. Há que notar, porém, a intenção hobbesiana de apresentar seu modo de ver a dialética do público e do privado, que também corresponde não só a uma substituição - veremos os motivos desta mais abaixo - mas a um distanciamento: entre aquilo que deve ser visível aos olhos de todos (o "público" encarnado na pessoa do soberano), e aquilo que deve permanecer invisível (o "privado", isto é, seus súditos).

Mais interessante ainda: em Hobbes, o autor, o ser representado, que deve permanecer oculto, é menos um criador do que a fonte da autoridade soberana (daí a idéia da "autorização" para agir). E isso nos remete a uma outra dialética, mais 
filosófica, paralela a do autor/ator: a da aparência e da essência. É estranho falar assim sobre um filósofo que quase todos os estudiosos consideram, em termos ontológicos, um "nominalista" e não um "essencialista". Contudo, a esse nominalista não seria estranho pensar que o representante (a "aparência") pode e deve substituir completamente o representado (a "essência"), e que, na verdade, esse último nada pode ser sem o primeiro. Se quiséssemos radicalizar a idéia - de modo algum fora do espírito da teoria política hobbesiana -, poderíamos dizer mesmo que, nesses termos, o ator-representante, em sua metamorfose, "recria" o autor-representado, invertendo os pólos do processo criativo: a fonte da autoridade política, de criador, se torna criatura de sua criatura. Precisamos agora recorrer ao retrato para elaborar melhor esse ponto.

\section{A representação como retrato}

Pensemos o retrato não como uma reprodução fiel de todas

234 as particularidades do retratado, não como um mero espelho dele, mas como um trabalho de construção do artista a partir do material bruto que tem diante de si. Supomos, assim, que o artista não quer capturar o retratado em qualquer situação, mas numa perspectiva especial - digamos, numa situação solene que então é congelada no retrato. Essa situação poderia ser aquela em que o próprio retratado desejasse ser visto pela posteridade, se o trabalho artístico lograsse identificar ou ressaltar algum aspecto essencial da sua personalidade, ou então idealizar, na perspectiva retratada, um tema para sua personalidade.

Em seu estudo sobre a construção da imagem pública de Luís XIV, A fabricação do rei, Peter Burke destaca essa característica dos retratos reais que investigou, invocando a consciente necessidade de ocultar, no retrato, a pessoa comum - aquilo que o nivelaria a todos os seus súditos para sobressaltar a pessoa especial e superior: 
"A maioria das pinturas do rei se enquadra no gênero a que os historiadores da arte chamam de 'retrato solene', construídas segundo a 'retórica da imagem' desenvolvida durante o Renascimento para a pintura de pessoas importantes. Nesses retratos solenes, a pessoa é geralmente apresentada em tamanho natural ou até maior, de pé ou sentada num trono. Os olhos do retratado estão acima dos olhos do espectador, para sublinhar sua posição superior. $\mathrm{O}$ decoro não permite que ele seja mostrado usando as roupas do dia-a-dia. Usa armadura, como símbolo de coragem, ou roupas ricas, como sinal de posição social elevada, e está cercado por objetos associados ao poder e à magnificência - colunas clássicas, cortinas de veludo etc. A postura e a expressão transmitem dignidade" (Burke, 1994: 31).

O autor dessa passagem lembra que Luís XIV não era representado apenas no retrato, mas em variadas manifestações artísticas, inclusive literárias (poesia) e teatrais. Mas o aspecto importante que quero ressaltar aqui é menos o tipo de manifestação artística do que a idéia abstrata de "retrato" que todas essas representações do rei indicam. Em pintura, escultura, literatura ou teatro, é da exposição do caráter elevado, especial, da personalidade do soberano que se trata. Isso é o retrato. Se quisermos, é uma certa inclinação ao gênero lírico, mais do que aos gêneros épico ou dramático, que o retrato expressa ${ }^{3}$. É claro que sempre podemos encontrar algo de lírico ou épico numa peça dramática, e

3. "Há uma certa unanimidade em considerar o gênero lírico o mais subjetivo [...] A essência da expressão lírica é a fusão entre Eu e Mundo; não há distância entre sujeito e objeto. Uma e a mesma atmosfera envolve, de modo indiferenciado, alma e universo. O gênero épico é mais objetivo. O Eu épico (o foco narrativo), embora faça parte do mundo imaginário, encontra-se nitidamente em face do mundo narrado [...] O gênero dramático se apresenta como o mais objetivo. O mundo fictício é proposto como inteiramente emancipado de qualquer subjetividade. Nenhum Eu lírico ou épico se interpõe. A ficção se apresenta como absoluta e autônoma, pelo menos no 'drama rigoroso'” (Rosenfeld, 1993: 38-39). 
vice-versa, assim como elementos desses três gêneros clássicos em todas as formas de expressão, plásticas ou não. Estamos falando aqui apenas de "formas puras", e não das misturas complexas que encontramos nas obras concretas e históricas em cada uma das grandes artes. Os termos "retrato" e "plástico", neste texto, traduzem apenas esse propósito.

Por certo, a atividade criativa do artista envolve uma sondagem ou investigação em torno do self do retratado. (Uso self menos no sentido psicológico moderno de um "ego", mas no sentido moral de um caráter ou uma qualidade de caráter de alguém: é assim que os falantes de língua inglesa o usam de longa data, segundo os dicionários. Ver, por exemplo, o verbete no Webster's Ninth New Collegiate Dictionary.) E provavelmente essa sondagem também exige que ele não se deixe confundir pela manifestação ostensiva, porém flutuante, do self "aparente" ou "empírico" que acaso o retratado exiba rotineiramente. Sua criação, pelo contrá236 rio, deve cavar uma distância dessa manifestação, para que possa captar-lhe seu self "profundo" ou "essencial”. Talvez o próprio retratado só tenha uma noção vaga do que isso significa; porém, mesmo que fosse capaz de sugerir sua idéia substantiva, careceria dos recursos para colocá-la numa for$m a$, pois o retratado não necessariamente domina a arte. $\mathrm{E}$ a última propõe resolver justamente este problema crucial: dar ao conteúdo bruto uma forma adequada. Nesse sentido, o próprio rei é o "ser representado", na medida em que seu material é o mesmo de todas as pessoas comuns, seus súditos. Só se torna "ser representante" como pessoa pública, isto é, para usar a terminologia de Hobbes, quando deixa de ser pessoa natural para transformar-se em pessoa artificial. Arte, artificialidade e "fabricação", aliás, são termos bastante próximos, e, contanto que não a interpretemos moralisticamente ou pela chave do cinismo, sugerem muito bem o contexto filosófico mecanicista do pensamento hobbesiano. Porém, tanto no caso da arte quanto da política, 
indicam que seu problema fundamental não é o conteúdo bruto, que é dado, mas sua síntese numa forma adequada.

A teoria do soberano de Hobbes pretende então resolver dois problemas que o trabalho do retrato também precisa resolver: a) como recolher o múltiplo numa unidade; e b) como, fazendo essa síntese, transcender a mera aparência da coisa a partir da qual a obra se faz. A idéia da máscara sugere a distinção entre o self espontâneo, que é a "pessoa natural" do soberano, e o self que a figura do soberano personifica oficialmente, como representante dos súditos. O que ele personifica oficialmente, porém? No trecho citado acima, Rosenfeld fala do ator trágico personificando forças ou seres divinos. E Burke lembra que Luís XIV, bem na linha do chamado "direito divino dos reis", se faz passar por representante de Deus na Terra: "Luís tomava também o lugar de Deus, como foi assinalado pelo pregador da corte Jacques-Bénigne Bossuet e outros teóricos políticos. Os soberanos eram 'imagens vivas' [images vivantes] de Deus, 'os representantes da majestade divina' [les représentants de la majesté divine]" (Burke, 1994: 21).

Sabemos, por outro lado, como famosamente Luís XIV se identificou com o próprio Estado. É neste ponto que a teoria da soberania de Hobbes, pelo menos em parte, se encaixa. Sua perspectiva secularista o levava a pensar o Estado não como uma entidade divina, mas como um artefato humano, fruto da vontade de cada um de seus próprios súditos. Daí que o Leviatã seja um "deus" mortal, não o Deus divino dos cristãos ou dos judeus, mas um produto de seres igualmente mortais. Porém, o modo como caracterizou seu estado de natureza não deixava margem para se pensar numa comunidade humana estável anterior à construção do soberano. Ambos, soberania e comunidade política, são obras concomitantes. Logo, o caráter absolutista de sua teoria: a comunidade política tem de estar subordinada ao Estado, personificado no soberano. Isso implica, para resga- 
tar o estudo de Quentin Skinner sobre o significado moderno deste termo, que o Estado soberano virtualmente substitui a comunidade - coloca-se no lugar dela, ou melhor, age e fala em seu nome.

Assim, o self que a soberania hobbesiana personifica não é seu próprio Eu, mas o Nós, a identidade da comunidade política, que, por sua vez, não tem uma existência natural independente, mas é construída através da obra do soberano. Essa interpretação, creio, casa-se razoavelmente bem com a metafísica nominalista do autor. Isso significa que o soberano não é um simples reflexo de um ser dado, mas também não é a ocupação, por um sujeito concreto qualquer e com todos os seus caprichos, de um lugar vazio, como se aquele lugar não implicasse certas obrigações e responsabilidades substantivas, inescapáveis a uma autoridade política. Na idealização hobbesiana, tem de haver um meiotermo entre uma noção excessivamente substantivista da 238 soberania (algo como um "populismo") e seu oposto excessivamente formalista e personalista.

Se o soberano não é a simples manifestação de seu próprio $\mathrm{Eu}$, não é também mero porta-voz de seus súditos. $\mathrm{O}$ Nós da comunidade política não é síntese empírica da vontade de seus súditos. Para começar, esse elemento de identidade tem de sobreviver à própria existência concreta dos súditos de carne e osso. O Leviatã, ao contrário do "Estado imortal” (porque divino) de Bossuet, é um deus perecível, mas sua construção é projetada para persistir indefinidamente, certamente para muito além do ciclo normal, biológico, de cada geração de súditos e também da pessoa natural do soberano. Aliás, Luís XIV foi lembrado disso por Bossuet, o que não deixa de matizar a célebre sentença em que identificava sua pessoa com o Estado: "No entanto, representar o Estado não é o mesmo que ser identificado com ele. Bossuet lembrou ao rei que ele morreria, ao passo que seu Estado deveria ser imortal, e, ao que se conta, Luís falou 
em seu leito de morte: 'Vou partir, mas o Estado permanecerá depois de mim' [Je m'en vais, mais l'État demeurera après moi]" (Burke, 1994: 21)

O que, portanto, a figura do Soberano captura, e tem de capturar, é essa permanência, que traduzo aqui na idéia do retrato: o soberano-representante à Hobbes é, no fundo, a marca de um self essencial - o Nós da comunidade política - como algo distinto do self empírico, que pode perfeitamente variar ao longo do tempo, sem que o outro sofra a mesma variação. Esta é a figura do Estado soberano.

A imagem hobbesiana da "máscara" poderia então ser explorada nesse sentido plástico que indiquei acima. A máscara não toma o representado em seu movimento ou em suas flutuações, mas o congela. Congela-o, porém, não em qualquer momento, mas numa situação ou perspectiva especial - aquela que supostamente lhe captura a identidade. Como um retrato, a máscara deixa de lado as qualidades secundárias de seu rosto, para ressaltar ou destacar suas qualidades essenciais. A máscara é a representação de um caráter, um aspecto fixo da personalidade. A construção da soberania política supõe esse trabalho sutil de pintura do retrato, cujo pintor é, na tradição do pensamento político, idealizado num "legislador".

Contudo, esta última frase sugere que façamos alguma qualificação à idéia da fixidez da personalidade pública do soberano. O legislador põe as leis fundamentais do Estado, sua Constituição. Identifico essa figura com a do artista/ agente político que fornece a "doutrina oficial" e a ordem jurídica básica para o Estado soberano. Porém, assim como a formulação dessa doutrina e dessa ordem é uma "arte", também o será a sua interpretação ao longo do tempo. De modo que podemos fornecer uma visão dinâmica da metáfora plástica, na qual o self essencial não é posto apenas em sua construção inaugural, mas reposto no trabalho intermitente de sua interpretação no futuro, tarefa para a qual 
é chamado não só um corpo especializado de intérpretes (digamos, o corpo de juízes de um "Supremo Tribunal”), mas eventualmente - se quisermos dar um viés democrático à própria visão de Hobbes, o que certamente não era sua intenção - o corpo de todos os cidadãos da comunidade política, sem que isso deixe de significar uma subordinação desta ao Estado, visto agora como representação daquela ordem jurídica básica.

Neste ponto, podemos compreender o quanto essa doutrina da representação se distancia de uma interpretação excessivamente personalista do soberano. Se é verdade que a democracia não está em seu horizonte, a postulação de uma ordem jurídica como elemento crucial de uma teoria normativa do Estado soberano é muito clara na visão hobbesiana ${ }^{4}$. Nela, as leis supremas do Estado são expostas de um modo bem generalizado, na forma das "leis de natureza” (Hobbes, 1983, Parte I, caps. XIV e XV). É verdade

240 que o autor nunca deixa de lembrar o caráter voluntarista das leis civis, decretadas pelo Soberano, dado que as leis de natureza são subjetivamente interpretadas por sua pessoa. Mas Hobbes faz questão de dizer que as leis de natureza não são idênticas a uma vontade humana caprichosa e volúvel - seja ela a de um homem ou "uma assembléia de homens" - mas são "certas conclusões, ou teoremas" da razão e, portanto, são “eternas e imutáveis” (Hobbes, 1983, Parte I, cap. XV) ${ }^{5}$.

Mas o conhecimento dessas leis não é o produto de uma revelação milagrosa. Trata-se, como ele diz no De cive

4. Sei que falar de uma "teoria normativa do Estado" em Hobbes é controverso, mas não estranho aos estudiosos do autor. Ver o trabalho de E. Curley (1989-1990: 187 e ss.), para um balanço da questão.

5. Essa observação permite diminuir o impacto da crítica à "authorization view", salientada por Pitkin e outros, da qual Hobbes seria um dos expoentes. Há que reconhecer um elemento de formalismo nessa visão, mas em Hobbes ela é complementada por certas "obrigações" substantivas do soberano, derivadas das leis de natureza. 
(On the Citizen, na tradução inglesa), de um trabalho da razão, cuja faculdade é ver o bem futuro, e não apenas dos sentidos externos, que só vêem o bem presente (Hobbes, 1998, Parte I, cap. III: 55). O Soberano é guiado, assim, por princípios que transcendem desejos e interesses passageiros de seus súditos, e de seus próprios, levando em conta acima de tudo o bem permanente deles. Por isso, o Soberano não tem nenhuma obrigação de atender àquilo que seus súditos reclamam, individual ou coletivamente, nesse ou naquele momento, mas apenas ao que sua pessoa pública considerar condizente com aquele bem.

É esse enfoque que vai permitir Skinner aproximar a visão hobbesiana da de outros teóricos da soberania absoluta do século XVII, e tratá-lo como o autor que mais consistentemente procurou resolver os problemas conceituais que esse tipo de teoria traz à tona. "O governo civil”, diz Skinner, "não pode ser visto [no enfoque hobbesiano] como igual aos poderes dos cidadãos sob uma outra roupagem. Ele deve ser visto como uma forma distinta de poder, por razões que Hobbes anuncia com completa segurança no De cive [...]: 'Embora um governo', ele declara, 'seja constituído pelos contratos de homens particulares com particulares, o direito [desse governo] não depende daquela obrigação apenas'. Ao constituir tal governo, 'aquele direito que cada homem possuía antes de usar suas faculdades para suas próprias vantagens é agora totalmente traduzido em um certo homem ou conselho de homens para o benefício comum'. Segue-se que todo poder instalado com autoridade deve ser reconhecido 'como tendo seus próprios direitos e propriedades, de tal modo que nenhum cidadão, ou todos eles juntos' podem agora ser considerados seu equivalente" (Skinner, 1989: 118).

Com essa leitura, Skinner não só mostra por que o conceito moderno de Estado tem de aparecer como devedor de uma idéia de representação como "autorização", mas tam- 
bém por que o soberano-representante não deve ser reduzido nem às "pessoas naturais" dos ocupantes de cargos públicos (inclusive a do supremo magistrado), nem ao conjunto de seus cidadãos.

\section{A representação como drama}

Passemos agora à metáfora dramática. Gostaria de pensar o drama como a representação de uma situação crítica: o conflito social. Ao contrário da perspectiva do retrato, nesta o self da comunidade política deve aparecer como problemático. Isto é, não se trata de construir um soberano no qual o self "essencial" se destaque de sua manifestação "empírica”, porque essa distinção já implica o desatar da situação crítica. Trata-se antes de pensar a personalidade pública da comunidade como repartida em dois ou mais selves, colocados numa polarização não resolvida. Essa forma de representação é o que o drama permite expressar.

242 Quero, porém, usar a metáfora dramática para me aproximar da noção tradicional de "Constituição Mista", que é um modo clássico-antigo de abordar o tema da boa ordem política. A teoria da Constituição Mista tornou-se muito conhecida através da obra do historiador grego Políbio, pela interpretação que oferecia do sistema político romano e pelo impacto que teve posteriormente no pensamento medieval e moderno. Mas ela é certamente anterior a Políbio. A teoria é uma elaboração em torno da idéia de que o melhor regime político é uma combinação ou mistura das "formas simples" - os autores variam quanto à designação e caracterização dessas formas; Políbio fala em três: realeza, aristocracia e democracia. Como essas formas operam com princípios distintos, mesmo antagônicos, a Constituição Mista é também uma teoria do equilíbrio entre instituições governamentais ou poderes constitucionais, cada qual representando esses distintos princípios. Como observa Von Fritz (caps. IV e VIII), provavelmente o estudo mais comple- 
to do tema em Políbio, a Constituição Mista é uma espécie rudimentar, avant la lettre, da teoria dos checks and balances e, ao mesmo tempo, uma teoria do equilíbrio constitucional entre grupos ou forças sociais em competição. Vou me restringir, nesta seção, a esse último aspecto, para desenvolver uma teoria da representação implícita nele.

No estudo a que me referi no início deste artigo (Araujo, 2004), parto da noção, predominante no pensamento antigo, de que os grupos sociais competidores são "ordens" ou "estamentos" (no sentido weberiano): nobres e plebeus, aristocracia e povo etc. Contudo, por considerar que a teoria poderia ter relevância para a compreensão da política moderna, amplio a noção de modo a abarcar classes socioeconomicamente definidas: ricos e pobres, grandes e pequenos proprietários, proprietários e não proprietários etc. Tendo em conta essa possibilidade mais ampla, diferencio uma versão "aristocrática” e uma versão "plebéia” da Constituição Mista. Na tradição da Antigüidade clássica, praticamente não encontramos uma defesa da última, dada a recepção positiva da idéia de uma hierarquia fixa de status entre as ordens sociais, presente em quase todos os autores clássicos que chegaram até nós. Mas penso que o pensamento clássico moderno, quando glosou a teoria da Constituição Mista tradicional, abriu-se à idéia de uma versão plebéia, especialmente a partir de Maquiavel, que a desenvolveu na perspectiva da desejabilidade do conflito social aberto no interior da comunidade política ${ }^{6}$.

Penso que a versão aristocrática, embora possa ser apresentada na forma do drama, é menos "dramática" que a outra, desde que coloca em cena diferentes grupos sociais ou seja, os diferentes selves no interior da comunidade polí-

6. Esse ponto, celebremente formulado em seus Discursos sobre a Primeira Década de Tito Livio, Livro I, caps. 1 a 6, tornou-se quase um lugar comum na literatura secundária de Maquiavel e dispensa comentários aqui. 
tica - naquela hierarquia fixa de status. Na versão plebéia, porém, a distinção de status é rejeitada em prol de um ideal de igualdade política que, ao mesmo tempo, é compatível com um certo tipo de estratificação social. (Aplico outra vez o mote weberiano: igualdade política como eliminação da diferença "estamental", mas não necessariamente a de "classes".) Isso sugere a situação crítica, mais conflitiva que a aristocrática, que o drama precisa representar/expressar.

A Constituição Mista plebéia é um script, um roteiro da representação em sua forma mais conflitiva, a ser encenada na arena pública. Nessa arena devem ingressar atores rivais, que encarnam diferentes papéis. A própria Constituição, portanto, prevê o conflito ou a situação crítica, e prescreve aos atores rivais maneiras de lidar com ela. Note-se, porém, para mergulharmos um pouco mais na metáfora, que o roteiro não deve ser confundido com o próprio drama, tratando-se antes de uma indicação para a cena, que nesse sen244 tido valoriza o desempenho dos atores:

"O teatro, mesmo quando recorre à literatura dramática como seu substrato fundamental, não pode ser reduzido à literatura, visto ser uma arte de expressão peculiar [...] o espetáculo, como obra específica, por mais que se ressalte a importância da literatura no teatro literário, passa a ter valor cênico-estético somente quando a palavra funciona no espaço, visualmente, através do jogo dos atores [...] O ator, portanto, não é garçom. Participa do preparo do prato. A melhor prova disso é o fato de que quatro grandes atores, mesmo interpretando lealmente o texto, criam quatro personagens profundamente diversas ao representarem o mesmo Hamlet literário" (Rosenfeld, 1993: 27-28 e 33).

Contudo, o objetivo do roteiro e do jogo dos atores é evitar aquilo que, sem a arena política, poderia ser incontornável: o "derramamento de sangue", símbolo não só da 
violência, mas da dissolução da comunidade política. Notese que a teatralização política opera com um fim distinto, por exemplo, do teatro trágico, cujo desfecho tradicional é o derramamento de sangue, forma estética de resolução da hybris, o "excesso". Na arena política, ao contrário, encenase a moderação, porque com ela se pretende superar, "sublimando", aquilo que ameaçaria a comunidade toda vez que não houvesse a encenação pública (e política) do conflito: o "derramamento de sangue".

Podemos analisar a diferença entre as versões aristocrática e plebéia de Constituição Mista pelos diferentes desfechos que sugerem para seus "roteiros". No primeiro caso, idealiza-se a harmonia entre os grupos de status através de um desfecho completo ou perfeito do drama: um desfecho "catártico", em que toda a violência potencial é absorvida nos limites da encenação realizada na arena pública. A cena dos cidadãos rivais de uma mesma comunidade política - chamemo-la de cena civil - se basta, e isso porque, ao fim e ao cabo, cada ator sabe exatamente a sua posição, seu status. $\mathrm{O}$ conflito surge apenas quando um ou outro tenta ultrapassar esse limite, que no roteiro aparece como a virtualidade de um desequilíbrio, o qual só pode ser resolvido se o equilíbrio for restabelecido; como? na medida em que cada ator reencontre sua posição "natural" na hierarquia dos grupos sociais.

Já o roteiro da Constituição Mista plebéia tem de admitir precisamente essa transgressão, sem tratá-la como um desequilíbrio. Aqui, os atores não podem representar papéis que indiquem uma posição "natural" numa hierarquia fixa de status. Nesse sentido, o desfecho do roteiro não pode ser completo ou perfeito. Ele tem de se apresentar como uma espécie de obra aberta, suscetível de transformações ao longo da própria encenação. Desde que o conflito social é não só admitido, mas valorizado, o problema de como absorver um maior excedente de violência torna-se mais 
agudo. Não por acaso, autores que considero pioneiros na elaboração da teoria da Constituição Mista plebéia, como Maquiavel, foram levados a pensar a cena civil, que na Constituição aristocrática se basta, como não suficiente para tal absorção, exatamente porque os grupos sociais em conflito não se conformariam com a situação atual em que se encontrassem. Em outras palavras: a situação crítica, o conflito, é gerado por esse inconformismo, e a cena civil só em parte o resolveria. Daí a possibilidade de uma outra cena que a suplementasse, canalizando aquilo que permanecesse em excesso na primeira: a cena militar, o "teatro de guerra”.

Evidentemente, para que o roteiro como um todo "funcionasse", seria preciso que a cena civil e a cena militar estivessem perfeitamente separadas, de tal modo que não pudessem se apresentar nelas os mesmos atores. Na cena civil, são grupos sociais que, do interior da comunidade política, se deixam representar por atores desarmados, os quais buscam 246 deliberadamente soluções pacíficas para suas diferenças. Já na cena militar não são grupos sociais, mas comunidades políticas inteiras que se deixam representar em sua rivalidade irredutivel. É aqui que a própria violência é encenada. Não se trata, porém, de qualquer violência, mas de violência organiza$d a$. Se falo de guerra como um "teatro", é porque na tradição do pensamento político a guerra caracteriza uma situação crítica, conflitiva, entre comunidades políticas, a qual também admite um roteiro. Só que, nesse caso, o objetivo do roteiro militar é a supremacia (ou "vitória") de um dos contendores, enquanto o do roteiro civil é o convívio dos contendores.

Podemos interpretar a chamada "guerra civil", nesse sentido, como signo do fracasso da Constituição Mista plebéia. A guerra civil significa a implosão da comunidade política, ao esvaziar completamente a cena civil em prol da cena militar. Isto é, ela será o resultado da incapacidade de os atores de uma mesma comunidade política personificarem seus respectivos papéis constitucionais. Uma parte funda- 
mental do roteiro é simplesmente ignorada, sem que as partes conflitantes reconheçam umas às outras como diferentes comunidades políticas. E sem esse reconhecimento não é possível sequer que a cena militar seja encenada. (Estou sugerindo, portanto, que a representação da cena militar depende do sucesso da encenação do "roteiro civil".) A guerra civil não pode ser uma expressão da situação crítica idealizada pela Constituição Mista plebéia; trata-se mais propriamente de uma situação de limbo político, na qual a capacidade mesma de representar é suspensa ${ }^{7}$.

Deixo para uma outra ocasião a discussão dos problemas relacionados à cena militar e à face propriamente internacional da Constituição Mista plebéia, em especial as objeções normativas que poderíamos fazer à solução maquiaveliana de torná-la uma válvula de escape para o excedente de violência doméstico. Vou me concentrar aqui apenas no ambiente interno, civil, e esmiuçar um pouco mais o que implicaria a capacidade de representar numa Constituição Mista plebéia. Quero ressaltar os seguintes aspectos. Já foi indicado que o representante é sempre parte e não todo. A síntese comunitária é uma questão em aberto, que o script constitucional não pode determinar. Não cabe estabelecer nem que se descubra um Nós da comunidade política, disponível, ainda que em germe, a uma apropriação pela atividade representativa, nem que se o construa através dessa mesma atividade - como é o caso na figura do soberano-representante. Nem essencialismo, nem nominalismo, portanto. Soluções provisórias são deixadas ao desempenho dos atores. $\mathrm{O}$

\footnotetext{
7. Somos tentados, nesse ponto, a fazer aproximações com a visão hobbesiana da guerra civil como estado de natureza. Porém, Hobbes não distingue a guerra civil do estado de guerra em geral, o qual é identificado com o estado de natureza. Por exemplo, a guerra entre duas comunidades políticas é também qualificada como estado de natureza (ver Hobbes, 1983, cap.XIII: 76-77). É o que se quer evitar aqui. Diga-se de passagem, a crítica de Rousseau a esse modo hobbesiano de ver a guerra nos parece muito pertinente. (Rousseau, 1978, Livro Primeiro, cap. IV: 28.)
} 
importante é que a nenhum ator está prevista a capacidade de consumar a síntese. Os atores não competem ou lutam entre si por conta desse objetivo. Eles o fazem porque expressam pólos distintos, geralmente antagônicos, do espaço social, e esforçam-se por elaborá-los na arena pública.

$\mathrm{Na}$ verdade, há uma dupla abertura a que o desempenho dos atores tem de estar disponível. Por um lado, é claro, a abertura para o representado, o impulsionador da atividade representativa. Por outro, e não menos importante, a abertura para o ator adversário. De alguma forma, essas duas têm de se combinar ou se ajustar mutuamente para que o desempenho seja bem sucedido. O enfrentamento desse desafio, porém, parece mais plausível se deixarmos de lado a idéia de que o representante simplesmente substitui o representado na arena pública, ou coloca-se em seu lugar ou age em seu nome. Melhor seria pensá-lo como a expressão de um pólo social que pretende representar. Uso o termo 248 expressão para resgatar justamente a metáfora artística, e que é tão bem compreendido por Charles Taylor em seu estudo sobre a concepção de linguagem de Herder:

"Se a língua serve para exprimir um novo tipo de percepção, ela não pode somente tornar possível uma nova percepção das coisas, a capacidade de descrevê-las, devendo igualmente abrir novas formas de responder às coisas, novas formas de sentimento. Se, ao exprimir nossos pensamentos sobre as coisas podemos chegar a ter novos pensamentos, então, ao exprimir nossos sentimentos, podemos chegar a ter sentimentos transformados [...] A idéia revolucionária implícita em Herder foi a de que o desenvolvimento de novas modalidades de expressão nos capacita a ter novos sentimentos, mais potentes ou mais aprimorados, e por certo mais autoconscientes. Ao sermos capazes de exprimir nossos sentimentos, damos-lhes uma dimensão reflexiva que os transforma" (Taylor, 2000: 112). 
Assim, transportando a elaboração acima para nosso assunto, podemos dizer que o representante completa o representado, em vez de meramente substituí-lo. A figura do representante é resultado de uma carência política do representado, de que o primeiro procura dar conta. Diremos, então, para voltar ao problema da representação na Constituição Mista, assim: o representado é a face social do instituto da representação, enquanto o representante/ator é sua face política, sua expressão através de uma forma que busca transformar a percepção social do conflito. Uma não é nem deve ser o espelho da outra, e sim suas faces complementares, ao mesmo tempo em comunicação e tensão recíprocas.

Que haja comunicação é evidente. Mas de onde a tensão? Ela deriva do fato de que o ator/representante em cena estará em permanente interlocução com os demais atores/representantes. Sustentando, cada qual a seu modo, o conflito social, eles terão de fazer da engenhosidade de seu desempenho um fator crucial para manter aquele conflito em seu nível civil. Pode-se dizer, a propósito, que a virtude "soberana" do desempenho na arena pública é de fato a civilidade. ${ }^{8}$ Há deveres para com o representado, mas também para com os demais atores, e ambos nem sempre são coincidentes. Daí a tensão .

8. "The ideal of citizenship imposes a moral, not a legal, duty - the duty of civility - to be able to explain to one another [...] how the principles and policies they advocate and vote for can be supported by the political values of public reason. This duty also involves a willingness to listen to others and a fairmindedness in deciding when accomodations to their views should reasonably be made" (Rawls, 1996: 217).

9. A chamada "representação corporativa" não me parece ser a única fórmula, nem a melhor, para a Constituição Mista plebéia, pois ela fixa em demasia a posição social dos representados. E essa fixidez enrijece também o desempenho dos atores na arena pública. Não que essa fórmula não tenha de ser praticada: propriamente desenhado, o corporativismo é um elemento de estímulo/problematização da representação política. Mas isso significa que as corporações, de profissionais, setores econômicos etc. ainda se situam no lado social da representação. E, portanto, o bom desempenho do ator político também depende de um prudente distanciamento daquelas. Para um excelente encaminhamento do tema, ver o artigo de Nadia Urbinati neste volume, p. 191-228. 


\section{Duas soberanias e a crítica da representação}

Como indicado no início deste artigo, as metáforas do retrato e do drama remetem a duas maneiras distintas de pensar a soberania.

Na metáfora do retrato, o soberano-representante é uma construção que resulta de uma atividade de introspecção e síntese: a pintura do retrato é uma sondagem, uma atividade de discernimento na direção do self do representado, que o retrato busca congelar e sintetizar numa forma. $\mathrm{O}$ Estado soberano é sua manifestação política. Por isso, gostaria de chamar esse tipo de soberania de intrínseca. Na perspectiva do soberano-representante hobbesiano, a comunidade política tem de se deixar absorver completamente pelo Estado para que este possa, reapresentando-a, transcender qualquer cisão interna pela hipóstase de uma comunidade política homogeneizada, o "Povo" - por isso mesmo composta por indivíduos, e não grupos sociais, "estamentos", "classes" ou o que for.

250 Na metáfora do drama, contudo, coloca-se a rejeição mesma do ideal de síntese que o retrato propõe. Temos nela a expressão de um movimento perpétuo que impossibilita a identificação e o congelamento de um self da comunidade política. A constituição mista plebéia é uma ordem na qual duas ou mais "semicomunidades", na verdade grupos sociais em disputa, buscam sustentar uma mesma comunidade política - comunidade socialmente cindida, portanto, sem condições de criar para si um único e inequívoco locus decisório.

Isso quer dizer que a constituição mista plebéia renuncia a qualquer noção de soberania? De modo algum. Ocorre que a noção só emerge quando mergulhamos essa ordem política no ambiente da "sociedade das nações". A soberania permanece, portanto, conceitualmente dependente desse contexto externo, em que se supõe que haja entre as comunidades políticas ${ }^{10}$

10. Insisto: entre "comunidades políticas", não entre "indivíduos", como ocorre na teoria hobbesiana da soberania, que, portanto, não distingue qualitativamente a "guerra de todos contra todos" da guerra entre Estados. 
uma rivalidade que, no limite, seja resolvida no "teatro de guerra”. A soberania, nesse sentido, é extrínseca. Sem a hipóstase de um ente homogeneizado, o "Povo", de onde extrair um ideal de bem comum, a constituição mista plebéia apresenta seus elementos internos não só como antagônicos, mas em pé de igualdade. Para fins de decisão comum, seus interesses e suas pretensões político-morais apresentam-se com peso igual, embora rivais. E isso inviabiliza também a chance de extrair sua identidade de uma noção de bem comum baseada na preferência aristocrática: se o ordenamento constitucional não possui um vértice, igualmente não dispõe de uma "escala" de excelência que o leve a priorizar um conjunto de valores em detrimento de outros. De um sistema de corpos que giram em torno uns dos outros, atraindose, mas também repelindo-se, o máximo que se pode esperar em seu ambiente interno é que a política civil faça surgir uma "clareira" comum entre os grupos antagônicos - uma cena pública na qual possam intermitentemente repactuar os termos duradouros de sua convivência social e política. Mas essa clareira não aparece do nada, e só pode emergir da suposição de um ambiente externo que, comparativamente, esmaece a rivalidade interna e lhe projeta, a partir de fora, sua identidade.

De qualquer forma, a idéia de uma comunidade socialmente cindida sugere um desenho institucional no qual agências ou poderes constitucionais separados competem entre si e reclamam diferentes aspectos das responsabilidades públicas. Para ser exato, uma doutrina da divisão/separação dos poderes constitucionais, do tipo checks and balances, também pode se apresentar sob o invólucro da forma Estado. Contudo, o caráter intrínseco de sua soberania traz consigo a noção de um cume do processo decisório constitucional, e isso não se encaixa bem no espírito da doutrina. A figura do soberano estatal é também a figura da última instância decisória, contra a qual não há recurso nem con- 
trole. Mas a idéia de um soberano normativamente limitado ou contrarrestado por outros poderes, como bem sublinha Hobbes (1983, cap. XXIX: 194-195), é contraditória com esse conceito. Assim, sob os auspícios da soberania intrínseca, a doutrina da divisão dos poderes acaba tendo de apontar a instância de último recurso que cumpra o papel do soberano, caso os poderes não convirjam para um mesmo ponto. Porém, o espírito da separação dos poderes é precisamente deixar essa questão em aberto.

Dessa perspectiva, o problema do controle da representação esbarra em dificuldades talvez ainda maiores. Deixando de lado o impasse da regressão infinita que a idéia da relação controlador/controlado nos coloca (quem controla o controlador?), vamos assumir uma variante democráticorepresentativa da soberania estatal. Nessa, eleitores-cidadãos (evidentemente, teria de ser uma vasta maioria da população adulta de uma comunidade) escolhem representantes 252 para um Parlamento. Pela ótica de uma teoria hobbesiana "democratizada", a função da eleição seria autorizar o corpo legislativo a agir e falar em nome dos cidadãos que o elegerem. Como a autorização é feita aos representantes do Parlamento, sede do Poder Legislativo, este deve assumir o papel de Soberano. A rigor, adaptar uma teoria da democracia representativa à concepção original de Hobbes da soberania não é uma tarefa fácil ${ }^{11}$. Como a idéia de cume é fundamental na visão hobbesiana, parece que, numa democracia representativa, o soberano oscila entre o corpo dos eleitores (nos breves momentos das eleições periódicas) e o corpo legislativo. Em parte, leio a conhecida crítica de Rousseau à representação parlamentar nessa chave.

Rousseau é crítico da representação parlamentar porque vê nela uma usurpação da soberania do Povo. De fato,

11. Procurei enfrentar esse problema em Araujo (2000) e Araujo (2004), e os resultados, confesso, permanecem um tanto insatisfatórios. 
se o corpo de cidadãos tem sua própria identidade e sabe o que quer, como e por que haveria de transferir esse querer? Em primeiro lugar, se o soberano se define por uma vontade, essa não pode ser alienada sem ao mesmo tempo perder sua integridade, desde que a vontade não é dissociável do sujeito que a tem: "O poder pode transmitir-se; não, porém, a vontade" (Rousseau, 1978, Livro II, cap.1: 44). Nesse ponto, a crítica de Rousseau é uma implicação possível das próprias noções de vontade e cume presentes no conceito hobbesiano de soberania. Porém, esse é o aspecto puramente analítico ou lógico de sua objeção ao Parlamento como corpo soberano, isto é, como Poder Legislativo. Mas há também, em segundo lugar, a crítica de caráter mais substantivo e histórico, complemento indispensável da outra.

Rousseau vê na representação parlamentar uma especialização inaceitável no interior da cidadania. Essa especialização é o resultado de uma evolução moderna cuja origem é o governo feudal, inventor da instituição do Parlamento, ao qual são contrastadas as "antigas repúblicas”, que não a conheciam. A evolução moderna advém do crescente papel do dinheiro para viabilizar essa estrutura de representação, via impostos. Os deputados são então vistos como "representantes" num sentido negativo, por se especializarem em tomar decisões cruciais (legislativas inclusive) em lugar dos cidadãos-eleitores que, a fim de se desvincilharem de seus deveres maiores como cidadãos, pagam para que outros os cumpram em seu nome:

"É a confusão do comércio e das artes, é o ávido interesse do ganho, é a frouxidão e o amor à comodidade que trocam os serviços pessoais pelo dinheiro. Cede-se uma parte do lucro, para aumentá-lo à vontade. Dai ouro, e logo tereis ferros. A palavra finança é uma palavra de escravos, não é conhecida na polis. Num Estado verdadeiramente livre, os cidadãos fazem tudo com seus braços e nada com o dinheiro; longe 
de pagar para se isentarem de seus deveres, pagarão para cumpri-los por si mesmos" (Rousseau, 1978, Livro III, cap. $\mathrm{XV}: 106-107)$

Exatamente porque a intromissão do dinheiro corrompe a disposição do cidadão para servir a comunidade, algo análogo a uma "corvéia" seria a melhor fórmula para o exercício dos deveres cívicos: "Distancio-me bastante das idéias comuns, pois considero as corvéias menos contrárias à liberdade do que os impostos" (id. ibid.). Curiosamente, porém, a passagem acima também registra uma linha de continuidade entre o "governo feudal", denunciado por impor a subserviência às relações entre governantes e governados através da vassalagem, e o que poderíamos chamar de "ordem burguesa”, denunciada por sutilmente induzir a subserviência pela mediação imprópria do dinheiro no serviço público.

Mas há ainda um outro modo de Rousseau observar a 254 representação parlamentar que é de interesse especial aqui. É que o autor sugere um paralelo entre esse tipo de representação política e a moderna representação teatral, da qual ele também é crítico. Numa carta pública a D'Alembert, Rousseau faz objeções à introdução do teatro ao estilo parisiense em Genebra. Nessa carta, ele faz seguidas comparações entre o teatro antigo e o moderno, em favor do primeiro, salientando seus respectivos efeitos políticos e morais sobre o público. Falando, por exemplo, do drama grego, ele destaca o modo público/aberto de sua encenação - "Esses grandes e soberbos espetáculos que aconteciam a céu aberto [...]" - para contrastá-lo com o drama moderno, movido pela relação comercial entre o espectador/ pagante e o ator/profissional pago, por isso mesmo encenado em lugares fechados: "Seus [dos gregos] nada tinham da mesquinharia dos de hoje em dia. Seus teatros não eram erguidos pelo interesse e pela avareza; não se fechavam em obscuras prisões; os atores não precisavam fazer os especta- 
dores pagarem, nem contar com o rabo do olho as pessoas que viam passar pela porta, para terem certeza do jantar" (Rousseau, 1993: 91).

Quanto à representação política, é verdade que o pensamento de Rousseau se mostra bem mais flexível diante de situações concretas, como percebemos em suas Considerações sobre o governo da Polônia e sua reforma projetada. Lá, como lembram os comentadores, não sem uma certa perplexidade, Rousseau admite a "deputação", que considera inconveniente, mas inevitável em grandes Estados. Dessa vez, contudo, a inconveniência a que o autor quer se ater não é de ordem teórica - por exemplo, o argumento da (im) possibilidade da representação da vontade geral - mas de ordem prática: "O Legislador em corpo [o conjunto dos cidadãos reunidos] é impossível de corromper, mas fácil de enganar. Seus Representantes são dificilmente enganados, mas facilmente corrompidos e ocorre raramente que não o sejam. Tendes sob os olhos o exemplo do Parlamento da Inglaterra [...]" (Rousseau, 1982: 48). Como se vê, o autor nunca perde de vista esse modelo histórico da representação parlamentar, a Inglaterra. Assim, quando admite uma câmara de deputados, o faz alertando para os perigos de sua anglicização - em particular, a transformação dos representantes em políticos profissionais. Eis por que recomenda severamente a seus amigos poloneses, ao reformar a Dieta (o "parlamento" polonês), que tratem de mudar "freqüentemente os representantes", para tornar "sua sedução mais custosa e mais difícil"; que façam os representantes "seguirem exatamente suas instruções e prestarem contas rigorosamente a seus constituintes de sua conduta na Dieta" e assim por diante.

$\mathrm{O}$ autor insiste, entretanto, que nenhuma medida legal ou institucional de controle será eficaz se os "costumes" e a "opinião pública" não forem mantidos na qualidade moral adequada: "Nunca haverá boa e sólida constituição além 
daquela em que a Lei reinará sobre os corações dos cidadãos. Enquanto a força legislativa não for até lá, as leis serão sempre eludidas. Mas como chegar aos corações?” (Rousseau, 1982: 25). Ao se perguntar sobre meios, Rousseau lembra, então, como na carta a D'Alembert, da importância dos espetáculos cívicos, fundamentais para "comover os corações e fazer amar as pátrias e as leis": "Ousaria eu dizêlo? Por meio de jogos de crianças; por meio de instituições ociosas aos olhos dos homens superficiais, mas que formam hábitos queridos e afeições invencíveis". Outra vez, o exemplo que tem em vista são os espetáculos dos antigos, que imediatamente compara ao teatro moderno: "São as poesias de Homero recitadas aos gregos solenemente reunidos, não em cofres, sobre pranchas do palco e com o dinheiro na mão, mas ao ar livre e em corpo de nação, são as tragédias de Ésquilo, de Sófocles e de Eurípides, representadas freqüentemente diante deles [...]".

256 É como se, ao falar do teatro fechado, ele falasse ao mesmo tempo do Parlamento moderno, cujas sessões também poderiam ser descritas como dramas encenados numa "prisão" ou num "cofre", destinados a públicos selecionados por seu poder aquisitivo, e não a céu aberto, ao público em geral: "Se eles [os modernos] se reúnem é em templos para um culto que não tem nada de nacional, que em nada lembra a pátria e que é quase escarnecido; é em salas bem fechadas e a preço de dinheiro, para verem em teatros afeminados [...] é em festas em que o povo, sempre desprezado, nunca tem influência, em que a repreensão e a aprovação públicas não produzem nada" (Rousseau, 1982: 28-29). Note-se, portanto, que, se dermos um peso maior a esse último aspecto de sua crítica, a denúncia rousseauniana da usurpação da soberania popular por um Parlamento não está, fundamentalmente, centrada na representação em si mesma, mas nos modos de sua operação em condições em que o dinheiro, a profissionalização/especialização da 
vida política e sua conseqüente opacidade dêem o tom. Essa é, penso, uma crítica que deveria calar muito mais fundo, considerando-se as práticas contemporâneas, do que a objeção puramente teórica à democracia representativa. Mas ela deveria atingir também o modo alternativo com que projetei a boa ordem política, isto é, a Constituição Mista plebéia?

Cabe observar, de partida, que nessa alternativa o problema do locus decisório, que desorienta a perspectiva da soberania intrínseca em vista da dualidade corpo de cidadãos (eleitores)/corpo de representantes, não se apresenta numa teoria da representação sustentada na soberania extrínseca. A Constituição Mista não tem nada a objetar, ao contrário, só a estimular que haja diferentes centros decisórios, cada qual podendo reivindicar divergentemente a representação do Povo, desde que este não seja pensado como um ente homogêneo apto a providenciar um self inequívoco à representação. Além disso, desde que não é papel nem dever da estrutura de representantes mimetizar o self da comunidade, a dualidade entre os cidadãos-eleitores e seus representantes, mesmo a tensão nesse relacionamento, como já assinalado, não deve aparecer como um obstáculo à boa ordem política.

Quanto ao problema do controle da representação, há que antes ponderar sobre o que exercer o controle. Para a Constituição Mista, a questão normativa principal não é se a estrutura de representantes está cumprindo apropriadamente suas obrigações de promover, no lugar dos representados, suas vontades, pleitos ou interesses, sejam esses julgados a priori, pelos compromissos assumidos antes do mandato, ou a posteriori, pelos resultados concretos do exercício do mandato. Na verdade, é preciso ter em conta o contexto inteiro da representação: haverá, por um lado, a interface entre o social e o político e, por outro, a relação entre os próprios representantes na cena pública, em que cabe 
dramatizar o atrito social. No julgamento do desempenho dos representantes, é claro que se deve considerar a capacidade deles de levar à cena pública as queixas sociais dos diferentes estratos/grupos/classes da comunidade e então tensionar as instituições políticas e seus processos decisórios. Porém, o julgamento tem de atentar igualmente para a capacidade da representação de reelaborar as queixas, torná-las mais reflexivas, dando-lhes a forma adequada para obter uma recepção positiva na cena pública. A avaliação a ser feita nesse ponto é muito complexa, porque os atores políticos sempre deverão procurar um delicado equilíbrio entre a preservação de sua interface social e a manutenção da cena pública na qual encontram seus adversários políticos. Os representantes buscam, assim, uma dupla cumplicidade: com seus representados, sem dúvida, mas também com seus próprios adversários na cena pública. Controlar a representação, portanto, implica fazer o balanço de toda 258 essa trama.

As críticas mais abstratas de Rousseau à representação parlamentar são devedoras de sua concepção toda peculiar de soberania popular, que pende para o que chamei aqui de soberania intrínseca. Pelas razões expostas acima, não creio que elas atinjam a estrutura normativa da soberania extrínseca. Todavia, penso que suas objeções práticas, de maior conteúdo histórico, deveriam ser consideradas muito seriamente no desenho concreto de uma Constituição Mista plebéia. Haverá alternativas viáveis à mediação do dinheiro e à profissionalização da representação política, que aguçavam especialmente suas ansiedades? Não tenho resposta clara para essa pergunta; mas admito, sem esmiuçar argumentos, que tais práticas são muito difíceis de contornar num mundo onde a divisão social do trabalho é avassaladora, absorvendo o próprio fazer político. Contudo, se for assim, não há como subestimar o perigo que as espreita, tão bem sugerido por Rousseau em sua imagem teatral. Isto é, o perigo 
de que a cena pública se feche em si mesma, transformando-se numa espécie de "cofre" ou "prisão", impermeável ao conjunto dos espectadores e seus conflitos sociais; ou, pior ainda, permeável apenas aos espectadores dispostos a pagar o preço a ser cobrado na entrada. Por certo, esse é um dos maiores desafios colocados à representação política, agora e no futuro.

\section{Cicero Araujo}

é professor do Departamento de Ciência Política da USP, editor de Lua Nova e pesquisador do CNPq.

\section{REFERÊNCIAS BIBLIOGRÁFICAS}

ARAUJO, C. 2000. "República e Democracia”. Lua Nova 51: 5-30.

. 2004. "Quod Omnes Tangit: Fundações da República e do

Estado”. Tese de Livre-Docência. Departamento de Ciência Política, FFLCH-USP. Mimeo. São Paulo.

BURKE, P. 1994. A fabricação do rei. A construção da imagem pública de Luís $X I V$. Rio de Janeiro: Zahar.

COULANGES, F. 2004. A cidade antiga. São Paulo: Martin Claret.

CURLEY, E. 1989-1990. "Reflections on Hobbes: recent work on his moral and political philosophy". Journal of Philosophical Research XV: 169-250.

DAHL, R. 1989. Democracy and its critics. New Haven: Yale University Press. HOBBES, T. 1983. Leviatã ou matéria, forma e poder de um Estado eclesiástico e civil. São Paulo: Abril Cultural. Coleção Os Pensadores. 1998. On the Citizen. Cambridge: Cambridge University Press.

MAQUIAVEL, N. 1970. The Discourses. Penguin Classics. Londres: Penguin,. PITKIN, H. 1967. The Concept of Representation. Berkeley: University of California Press.

POLÍBIO 1954. The Histories. Vol. IV. Loeb Classicas Library. Cambridge (Mass.): Harvard University Press.

RAWLS, J. 1996. Political Liberalism. Nova York: Columbia University Press. ROSENFELD, A. 1993. Prismas do Teatro. São Paulo: Perspectiva.

ROUSSEAU, J.-J. 1978. Do Contrato Social. Coleção "Os Pensadores". São Paulo: Abril Cultural.

1982. Considerações sobre o governo da Polônia e sua reforma projetada. São Paulo: Brasiliense.

1993. Carta a D'Alembert sobre os espetáculos. Campinas: 
Editora Unicamp.

SKINNER, Q. 1989. "The State”. In: FARR, J., BALL, T. e HANSON, R. L. (orgs.) Political Innovation and Conceptual Change. Cambridge: Cambridge University Press.

TAYLOR, C. 2000. Argumentos filosóficos. São Paulo: Loyola.

VON FRITZ, K. 1954. The Theory of the Mixed Constitution in Antiquity: A critical analysis of Polibius' political ideas. Nova York: Columbia University Press.

WEBSTER'S Ninth New Collegiate Dictionary. 1991. Springfield (Mass.): Merriam-Webster. 


\section{REPRESENTAÇÃO, RETRATO E DRAMA}

CICERO ARAUJO

$\mathrm{O}$ artigo vale-se de duas metáforas artísticas para explorar um contraste entre maneiras de pensar a representação política. As metáforas sugerem duas idealizações muito diferentes da boa ordem política, ainda que o vocabulário político tradicional costume confundi-las, e produzem seus 
próprios impactos a respeito do que esperar das práticas de representação das autoridades políticas.

Palavras-chave: Retrato e drama; Representação; Estado soberano; Constituição Mista.

\section{REPRESENTATION, PORTRAIT AND DRAMA}

The article elaborates on two artistic metaphors to search for contrasting modes of thinking on political representation. The metaphors suggest two very distinctive ideals of the good political order - despite a certain trend of the traditional political lexicon to mix them up - and make their own impacts on what to expect from the authorities' practices of representation.

Keywords: Portrait and drama; Representation; The sovereign State; Mixed Constitution. 